\title{
PENGUATAN KEMAMPUAN BENDAHARA DAN GURU SD MELALUI PEMBELAJARAN AKUNTANSI DASAR DI SDN MEKARWANGI, DS. MEKARWANGI, KEC. CISAUK, TANGERANG-BANTEN
}

\author{
Bahtiar Effendi \\ Jurusan Akuntansi, FEBIS, Matana University, Gading Serpong, Tangerang, 15810 \\ Email: bahtiar.effendi90@gmail.com
}

\begin{abstract}
This activity aims to provide an adequate learning about the basic accounting of nonprofit entities to strengthen the ability of treasurers and teachers in recording and reporting of school financial books. The target of this activity is the teachers especially the school treasurer of SDN Mekarwangi. Problems resolved through two stages of learning and mentoring activities. The results of this activity show a positive impact with the improvement of teachers' skills related to school bookkeeping with the provision of the Principal's decision to appoint one teacher of the lesson participants to assistant treasurer. In addition, the results of other activities of the basic accounting concepts have been implemented in the private business of one of the teachers of the learning participants through the business of its sweet potato chips.
\end{abstract}

Keywords: strengthening ability; teachers and treasurers; learning and mentoring.

\begin{abstract}
Abstrak. Kegiatan ini bertujuan memberikan pembelajaran memadai mengenai akuntansi dasar entitas nirlaba guna penguatan kemampuan bendahara dan guru dalam pencatatan dan pelaporan pembukuan keuangan sekolah. Sasaran kegiatan ini adalah guru-guru terutama bendahara sekolah SDN Mekarwangi. Permasalahan diselesaikan melalui dua tahapan yakni kegiatan pembelajaran dan pendampingan. Hasil kegiatan ini menunjukkan dampak positif dengan peningkatan kemampuan guru terkait pembukuan sekolah dengan dibuktikannya keputusan Kepala Sekolah mengangkat satu guru peserta pembelajaran menjadi asisten bendahara. Selain itu, hasil kegiatan lainnya konsep akuntansi dasar telah diimplementasi dalam usaha pribadi milik salah satu guru peserta pembelajaran melalui usaha keripik ubinya.
\end{abstract}

Kata Kunci: penguatan kemampuan; guru dan bendahara; pembelajaran dan pendampingan

\section{PENDAHULUAN}

\section{Analisis Situasi}

Sekolah merupakan salah satu organisasi sektor publik di bidang pendidikan yang mempunyai peran penting dalam menghasilkan generasi yang berkualitas. Kemajuan sebuah bangsa ditentukan oleh kualitas sumber daya manusia. Sumber daya manusia sangat ditentukan oleh kualitas pendidikan, karakter, dan keterampilan. Ketiga faktor tersebut dapat dibentuk melalui proses pendidikan. Tujuan pendidikan nasional adalah membentuk generasi muda yang berkepribadian, cerdas, dan mempunyai keterampilan [10] (UU no. 20 tahun 2003). Mengingat pentingnya peran pendidikan mendorong pihak sekolah untuk terus meningkatkan kualitas atau mutu pendidikan bagi siswa [2] (Hapenciuc et al., 2007) [9] (Sihono dan Yusof, 2012).

Seorang guru kadangkali terlibat dalam proses transaksi kegiatan operasional sekolah, dimana kemampuan akuntansi dasar diperlukan terutama bagi guru yang menduduki posisi sebagai bendahara di sekolah. Kemampuan akuntansi dasar sangat penting dalam menunjang kegiatan operasional sekolah guna terciptanya pelaporan dana yang akurat dan dapat dipertanggungjawabkan. Dewan guru, khususnya bendahara harus memiliki pengetahuan dan kompetensi mengenai akuntansi dasar karena hal ini sangat dibutuhkan dalam pelaporan dana yang didapatkan sekolah . Peningkatan kualitas sekolah harus didukung dengan adanya dana, sumber daya manusia/tenaga pendidik dan material [2] (Hapenciuc et al., 2007). Sumber dana sekolah berasal dari Pemerintah Pusat, Pemerintah Daerah, dan Masyarakat [7] (Peraturan Pemerintah Nomer 48 tahun 2008). Saat ini dengan diterbitkannya [6] Peraturan Menteri Pendidikan dan Kebudayaan RI No 161 Tahun 2014 tentang petunjuk teknis penggunaan dan pertanggungjawaban keuangan dana bantuan operasional sekolah (BOS) tahun 2015, 
mengharuskan seorang guru yang bertugas bendahara sekolah untuk dapat melaporkan dana BOS secara akurat sesuai dengan penerimaan dan pengeluaran biayanya.

Teori Agency awalnya digunakan dalam sektor privat yang melibatkan pemilik sebagai principal yang tidak dapat mengelola sendiri perusahaannya dan menyerahkan tanggung jawab itu kepada manajer selaku agent. Melihat kewajiban pelaporan tersebut tentu sesuai dengan teori keagenan menurut [3] (Hill dan Jones, 1992) yang menyatakan bahwa teori agency dan stakeholder merupakan cara strategis organisasi dalam mencapai tujuannya. Sekolah sebagai lembaga pendidikan di sektor publik melibatkan beberapa stakeholder baik stakeholder internal maupun stakeholder eksternal. Kepala sekolah dan jajarannya dapat disebut agent, dan pemerintah disebut principal. Pengelola keuangan sekolah selaku agen mendapatkan fasilitas dan dana dari pihak principal. Pengelola bertanggung jawab atas pengelolaan dana untuk pendidikan dan pelaporan dana tersebut. Perbedaan kepentingan antara agen dan principal dapat menyebabkan terjadinya konflik. Oleh sebab itu, untuk menurunkan biaya keagenan dan meredam konflik diperlukan media pelaporan pertanggungjawaban mengenai pembukuan dana BOS.

Selain menjadi kebutuhan dalam pelaporan dana di sekolah, akuntansi dasar juga dapat menjadi bekal bagi dewan guru/ bendahara sekolah dalam mengelola, melaporkan dan menganalisa kegiatan yang berkaitan dengan keuangan pribadi mereka. Hal ini penting dalam menganalisa dan memutuskan strategi dalam merencanakan keuangan masing-masing.

Pembelajaran merupakan kegiatan yang dilakukan untuk menciptakan suasana atau memberikan pelayanan agar siswa belajar, pembelajaran lebih menekankan pada guru dalam upayanya untuk membuat siswa dapat belajar tidak hanya membuat adanya perubahan tingkah laku siswa [8] (Sardiman, 2011: 20-21). Dapat disimpulkan pembelajaran akuntansi adalah proses membuat orang belajar atau rangkaian kejadian yang mempengaruhi siswa sehingga proses belajarnya dapat berlangsung mudah untuk menyampaikan sekumpulan materi bahan ajar berdasarkan landasan keilmuan akuntansi yang akan dibelajarkan kepada peserta didik sebagai beban belajar melalui metode dan pendekatan tertentu.

SDN Mekarwangi berlokasi di Kp. Pasir Awi Rt. 014/015, Desa Mekarwangi Kec. Cisauk Kabupaten Tangerang. Sekolah tersebut merupakan mitra binaan pengabdian masyarakat bagi Universitas Matana disamping mitra binaan KTLH Sangga Buana Jakarta. Saat ini, jumlah tenaga pendidik SDN Mekarwangi berjumlah 9 orang ditambah 1 orang sebagai penjaga sekolah. Adapun status tenaga pendidik adalah 2 guru PNS dan 7 guru honorer). Dengan keterbatasan tenaga tersebut, $\mathrm{Bu}$ Aty selaku kepala sekolah mengharapkan agar posisi bendahara yang sekarang ditempati oleh Bp Doni dapat disupport oleh tenaga pendidik yang lain karena harus ada yang dapat menjalankan peranan bendahara sekolah apabila bendahara sedang ada kegiatan dinas luar.

Berdasarkan kondisi tersebut, dosen Fakultas Ekonomi dan Bisnis Universitas Matana merasa perlu melaksanakan pengabdian masyarakat yang berupa pembelajaran akuntansi dasar yang diperlukan oleh guru dan khusunya bendahara di SDN Mekarwangi tersebut.

\section{Permasalahan Mitra}

Mengacu pada analisis situasi, persoalan prioritas yang disepakati untuk diselesaikan selama pelaksanaan program pengabdian masyarakat di Desa Mekarwangi adalah meningkatkan kemampuan bendahara dan guru SDN Mekarwangi, khusunya dalam pembelajaran akuntansi dasar guna mendukung kegiatan pencatatan transaksi keuangan dengan keterbatasan sumber tenaga pengajar SDN Mekarwangi. Selanjutnya, orang yang mampu dan mengerti mengenai pencatatan keuangan sekolah hanyalah satu orang yakni Bp Donni selaku bendahara sekolah yang mana beliau terkadang memiliki kesibukan yang tidak dapat ditinggalkan seperti rapat dengan dinas pendidikan setempat juga harus mengorbankan jam mengajarnya di SDN Mekarwangi. Tujuan diadakannya pembelajaran akuntansi agar dapat menambah tenaga pendidik yang menguasai 
akuntansi guna mendukung kegiatan operasional sekolah dengan tenaga pendidik yang terbatas.

\section{Solusi yang ditawarkan}

Untuk menyelesaikan permasalahan yang dihadapi mitra, solusi yang ditawarkan adalah melakukan pembelajaran akuntansi dasar. Oleh karena itu, materi pembelajaran meliputi hal-hal berikut ini:

1) Pengenalan konsep dasar akuntansi

2) Membuat penjurnalan dan pengenalan akun pendapatan dan beban

3) Proses pencatatan transaksi akuntansi

4) Penyelesaian siklus akuntansi

5) Penerapan akuntansi organisasi nirlaba (sekolah)

6) Review pertanggungjawaban, pencatatan dan pelaporan dana BOS melalui Alpeka.

Desain materi pembelajaran di atas diharapkan dapat meningkatkan beberapa kemampuan guru dan mencetak guru yang memahami akuntansi khusunya bendahara, dengan kemampuan berikut ini:

1) Pengetahuan tentang dasar akuntansi

2) Menganalisa pendapatan dan beban terkait kegiatan operasional sekolah SDN Mekarwangi

3) Pengetahuan tentang pelaporan pertanggungjawaban dana organisasi nirlaba (dana bos menggunakan Alpeka).

Luaran yang ditargetkan dari kegiatan pembelajaran pengabdian masyarakat ini meliputi:

1) Peningkatan pemahaman terkait pembelajaran akuntansi dasar (dibuktikan dengan penyelesaian soal latihan pembukuan sekolah).

2) Penambahan tenaga pendidik yang memahami dan menguasai teknik pencatatan akuntansi guna membantu bendahara dalam mencatat kegiatan operasional sekolah.

\section{METODE PELAKSANAAN}

Metode yang digunakan dalam pemecahan permasalahan adalah analisis deskriptif.

Kegiatan pembelajaran direncakanan dalam dua tahap, yaitu tahap pertama tentang konsep pembelajaran akuntansi dasar dengan langkahlangkah berikut ini: a. Penyampaian materi pembelajaran tentang akuntansi dasar

b. Penyampaian materi tentang kode etik, standar pencatatan yang berlaku

c. Praktik membuat laporan pertanggungjawaban dana operasional sekolah

Tahap kedua adalah pendampingan kegiatan:

a. Pendampingan pencatatan pembukuan sekolah dan evaluasi terkait pelaporan dana bos sekolah SDN Mekarwangi oleh bendahara dan guru yang ditunjuk kepala sekolah membantu bendahara

b. Pendampingan pencatatan pembukuan usaha keripik ubi milik salah satu guru SDN Mekarwangi (peserta pembelajaran akuntansi) yakni Bp Galih.

Adapun pelaksanaan kegiatan pembelajaran ini dilaksanakan pada:

Hari/ Tanggal : Kamis/ 13 April-12 Oktober 2017

Pukul $\quad: 10.00-12.00 \mathrm{WIB}$

Tempat : SDN Mekarwangi, Ds.

Mekarwangi Kec. Cisauk

Kabupaten Tangerang

Agenda : Pembelajaran akuntansi dasar

Instruktur $\quad$ : Bahtiar Effendi, SE.,M.Ak.

Kegiatan ini dihadiri oleh 2 guru dan 1 bendahara SDN Mekarwangi (dokumentasi kegiatan pembelajaran dan daftar hadir pelaksanaan pembelajaran disajikan dalam lampiran).

\section{HASIL DAN PEMBAHASAN}

Pembelajaran akuntansi dasar bagi bendahara dan guru di SDN Mekarwangi, Desa Mekarwangi Kec. Cisauk dihadiri oleh 1 bendahara dan 2 guru dengan prosentase kehadiran adalah 100\%. Pada saat pelaksanaan kegiatan pembelajaran terlihat antusiasme peserta dengan berbagai pertanyaan yang dilontarkan oleh peserta.

Pada saat proses pembelajaran khususnya analisa logika berfikir akuntansi, peserta diberikan Lembar Kerja isian untuk mencatat akun dan penyelesaian siklus akuntansi dasar.

Menurut Agus Suprijono (2011: 4-5) "belajar adalah perubahan perilaku sebagai hasil belajar, belajar merupakan proses dan belajar merupakan bentuk pengalaman". Menurut Nana Sudjana (2010: 28) "Belajar bukan menghafal dan bukan 
pula mengingat, belajar adalah suatu proses yang ditandai dengan adanya perubahan pada diri seseorang”. Menurut AICPA (dalam Kardiman dkk, 2009: 2), akuntansi adalah seni dari pencatatan, penggolongan, dan peringkasan dengan suatu cara tertentu dan dalam nilai uang terhadap kejadian atau transaksi yang paling sedikit atau sebagian bersifat keuangan dan penafsiran terhadap hasil-hasilnya. Jadi Hasil Belajar Akuntansi adalah akibat dari suatu aktivitas yang dapat diketahui perubahannya dan pengembangannya mengarah ke lebih baik dalam pengetahuan, pemahaman, penerapan, dan analisis setelah melalui suatu ujian dalam bidang akuntansi.

Adapun hasil kegiatan pembelajaran akuntansi yang mendasar adalah sebagai berikut:

1. Terdapat tambahan tenaga asisten bendahara, dimana Bu Aty selaku kepala sekolah SDN Mekarwangi mempercayakan dan menunjuk salah satu guru peserta pembelajaran akuntansi a.n Bu Novi sebagai asisten pendukung kegiatan bendahara. Saat ini, Bu Novi sudah terlibat dalam pencatatan pembukuan perusahaan dan sudah dipercayakan mengelola dana tabungan siswa SDN Mekarwangi yang akan dicairkan saat kenaikan semesteran.

2. Peningkatan kualitas pencatatan pembukuan keuangan SDN Mekarwangi melalui tambahan tenaga pendukung (asisten bendahara sekolah).

3. Disisi lain, salah satu guru peserta pembelajaran akuntansi sudah menerapkan metode pencatatan yang akuntabel terhadap kegiatan usaha pribadinya yakni pembuatan keripik ubi.

\section{SIMPULAN}

Kegiatan pembelajaran akuntansi dasar bagi bendahara dan guru di SDN Mekarwangi mendapat sambutan yang baik dari peserta. Keadaan ini dapat dilihat dari kehadiran peserta yang mencapai $100 \%$. Peserta terdiri dari bendahara dan dewan guru SDN Mekarwangi.

Karena keterbatasan waktu, kegiatan pembelajaran ini dilanjutkan dengan kegiatan pendampingan (monitoring) terkait pelaporan pembukuan sekolah oleh bendahara dan pencatatan pembukuan usaha pribadi milik salah satu guru peserta pembelajaran (Bp Galih).

\section{DAFTAR PUSTAKA}

Agus, Suprijono. (2011). "Model-Model Pembelajaran". Jakarta: Gramedia Pustaka Jaya.

Anonim. (2015). "Buku Monograf Desa Mekarwangi".

Hapenciuc, C. V. , A. Burciu, dan G. Cioban. (2007). "Implementation Of The System Of The Management of Education Quality, Basic Requirement For E.U. Integration". SSRN Journal:1-9.

Hill, Charles W.L., dan Jones Gareth R. (1998). "Strategic management Theory: An Integrated Approach". Fourth Edition, Houghton Mifflin, Boston.

Kardiman,dkk.(2009). "Prinsip-prinsip Akuntansi 1 SMA Kelas XI. Jakarta": Yudhistira.

Nana Sudjana. (2009). "Penilaian Hasil Proses Belajar Mengajar". Bandung: Remaja Rosdakarya.

ermendikbud. (2014). Peraturan Menteri Pendidikan dan Kebudayaan RI No 161 Tahun 2014 tentang Petunjuk Teknis Penggunaan dan Pertanggung Jawaban Keuangan Dana Bantuan Operasional Sekolah Tahun Anggaran 2015.

Republik Indonesia, Peraturan Pemerintah Nomor 48 Tahun 2008 Tentang Pendanaan Pendidikan, didownload dari http://pendidikan.jpd

Sardiman. (2011). "Interaksi dan Motivasi Belajar Mengajar”. Jakarta: PT Grafindo Persada.

Sihono, T., and Yosuf, R. (2012), "Implementation of School Based Management in Creating Effective Schools," International Journal of Independent Research and Studies, 1(4), 142-152.

Undang-undang RI No.20 tahun 2003 tentang sistem pendidikan nasional. 